\title{
The HLA-D associations of Type 1 (insulin-dependent) diabetes in Punjabi Asians in the United Kingdom
}

\author{
O.Odugbesan, J.Fletcher, C. Mijovic, E. Mackay, A. R. Bradwell and A. H. Barnett
}

Departments of Medicine and Immunology, University of Birmingham and East Birmingham Hospital, Birmingham, UK

\begin{abstract}
Summary. Type 1 (insulin-dependent) diabetes is less common in Asian Indians than in white Caucasoids. Forty-five Punjabi Asians with Type 1 diabetes and 96 racially matched control subjects were HLA-DR typed. DR3 was increased in diabetic patients vs control subjects $\left(82 \%\right.$ vs $38 \%, p<10^{-5}$ ) with relative risk 7.7 and etiological fraction 0.72 . DR4 was increased in diabetic patients vs control subjects (31\% vs $7 \%$, $p<0.003$ ) with relative risk 5.7 and etiological fraction 0.26 . DR2 showed a negative association (relative risk 0.19 , etiological fraction -0.28), as did DR7 (relative risk 0.21, etiological fraction -0.33). HLA-DQ $\beta$-chain gene probing using restriction enzyme BamHI in 43 diabetic patients and 90 control subjects showed that the DR1-associated 6.2 and $3.2 \mathrm{~kb}$ fragments were less common in diabetic patients than in the control subjects $(12 \%$ vs $36 \%, p<0.02)$. A $12 \mathrm{~kb}$ fragment was associated with DR4 in both diabetic patients and
\end{abstract}

control subjects. DR3 is the major susceptibility factor for Type 1 diabetes in Punjabi Asians and DR4 is a second marker. Gene probing indicates that the same DR4 subset is associated with the condition as in white Caucasoids. DR1 and its associated $\mathrm{DQ} \beta$ restriction fragments are reduced in Asian Type 1 diabetic patients making it unlikely that DR1 haplotypes carry a predisposing factor in this racial group. We conclude that the genetic component of Type 1 diabetes in Punjabis shows differences from that of the white Caucasoid population and that the lower frequency of DR4 in this population may contribute to the lower prevalence of Type 1 diabetes.

Key words. Type 1 (insulin-dependent) diabetes, Punjabi Asians, HLA-DR typing, DQ $\beta$-gene probing.
Studies of diabetes in India suggest that Type 1 (insulin-dependent) diabetes is considerably less common than in the United States or Europe [1-4]. In our clinic in Birmingham, United Kingdom only $4 \%$ of Asian diabetic patients have classical ketosis-prone, insulindependent diabetes compared with $18 \%$ of white Caucasoid diabetic patients [5]. On the other hand, the Southall UK survey [6] indicated that the prevalence of Type 2 (non-insulin-dependent) diabetes in the Asian population in the UK is substantially higher than in white Caucasoid subjects. The lower prevalence of Type 1 diabetes in Asian Indians may be due either to different genetic or environmental factors or both. We have studied the HLA-D region by both serological and gene probing techniques in Punjabi Asians living in the UK to determine whether the genetic factors responsible for the predisposition to Type 1 diabetes differ from those in white Caucasoid subjects.

\section{Subjects and methods}

Unrelated Asian Indian subjects with Type 1 diabetes attending 7 diabetic clinics in the West Midlands (Birmingham area of the UK) were studied. Type 1 diabetes was defined as ketosis-prone diabetes with acute onset of symptoms, absolute requirement for insulin from diagnosis and age at diagnosis less than thirty years. Healthy racially matched unrelated control subjects with no family history of diabetes were recruited from antenatal clinics and community centres. In all cases the subjects or both their parents were born in the Punjab region of the Indian subcontinent. Seventeen of the 45 diabetic patients were born in the UK and the remainder in the Punjab. In all diabetic patients, the initial diagnosis of Type 1 diabetes was made in the UK. One of the diabetic patients had autoimmune hypothyroidism, but there were no other patients with autoimmune polyendocrinopathy.

HLA-DR typing was performed in 45 Type 1 diabetic patients and in 96 control subjects. Southern blot hybridization analysis was performed in 43 diabetic patients and in 90 control subjects. Both analyses were performed in 43 diabetic patients and in 79 control subjects. For technical reasons the remaining subjects had only one of these investigations performed. Peripheral blood lymphocytes were enriched for B cells by depletion of T cells using sheep erythrocyte rosetting. HLA-DR antigens $1-5$ and 7 were identified by a standard microlymphocytotoxicity method [7] using commercially prepared typing trays (Biotest (UK), Birmingham, UK). Seven antisera were available for each of the specificities DR1-5 and five antisera for DR7.

DNA was isolated from peripheral blood of Type 1 diabetic patients and control subjects. $10 \mu \mathrm{g}$ DNA was digested with restriction 
enzyme BamHI under conditions recommended by the manufacturer (BRL, Glasgow, UK). Digested DNA was separated by electrophoresis in $0.7 \%$ agarose at $50 \mathrm{~V}, 25 \mathrm{~mA}$ for $18-22 \mathrm{~h}$ and blotted by the method of Southern onto nitrocellulose filters [8]. The HindIII/ PstI insert of pII- $\beta-1$ (DQ $\beta$ chain) (kindly provided by P. A. Peterson, Uppsala, Sweden), was labelled to a specific activity of $10^{9} \mathrm{cpm} / \mu \mathrm{g}$ DNA by the oligonucleotide primer method [9]. Prehybridization and hybridization were performed at $65^{\circ} \mathrm{C}$ in $6 \times$ standard sodium citrate solution (SSC; $1 \times \mathrm{SSC}=0.15 \mathrm{~mol} / 1 \mathrm{NaCl}, 0.015 \mathrm{~mol} / 1 \mathrm{Na}$ citrate), $5 \times$ Denhardt's solution, $0.5 \%$ sodium dodecyl sulphate (SDS) with $250 \mu \mathrm{g} / \mathrm{ml}$ denatured salmon sperm DNA. Ten percent dextran sulphate was used in the hybridization solution. After hybridization, filters were first rinsed in $2 \times \mathrm{SSC}, 0.1 \%$ SDS, twice, at room temperature, then washed in the same solution at $65^{\circ} \mathrm{C}$ for $30 \mathrm{~min}$. Washing was then performed in $0.5 \times \mathrm{SSC}, 0.1 \% \mathrm{SDS}$ at $65^{\circ} \mathrm{C}$ for $60 \mathrm{~min}$, followed by four 15 -min washes in $0.1 \times \mathrm{SSC}, 0.1 \% \mathrm{SDS}$ at $65^{\circ} \mathrm{C}$. After air drying, autoradiography was performed for 3 days at $-70{ }^{\circ} \mathrm{C}$.

\section{Statistical analysis}

The chi-squared test was used where all cells in a $2 \times 2$ contingency table had expected values greater than five. Otherwise, Fisher's exact test was employed. The $p$ values were corrected $\left(p_{c}\right)$ by multiplying by the number of $D R$ antigens tested. Relative risk (RR, a measure of the increased risk of developing the disease if exposed to a particular risk factor) and etiological fraction (EF, the proportion of the disease in the population that is associated with the risk factor) were calculated by standard methods [10].

\section{Results}

Results of HLA-DR typing are shown in Table 1. There was a strong positive association between DR3 and Type 1 diabetes with $82 \%$ of diabetic patients possessing DR3 in comparison with $38 \%$ of control subjects $\left(p_{\mathrm{c}}<10^{-5}\right.$, RR 7.7, EF 0.72). DR4 was also significantly increased in diabetic patients compared with control subjects $\left(31 \%\right.$ vs $\left.7 \%, p_{c}<0.003\right)$, with RR 5.7 and EF 0.26 . Ninety-one per cent of diabetic patients possessed DR3 and/or DR4 compared with $42 \%$ of control subjects $\left(p_{\mathrm{c}}<10^{-7}\right.$, RR 14.4, EF 0.85). DR 3,4 heterozygosity was increased in diabetic patients $(22 \%)$ compared with control subjects $(3 \%) \quad\left(p_{\mathrm{c}}<0.007\right.$, RR 8.9, EF 0.20). DR2 and DR7 showed negative associations with Type 1 diabetes, being more frequent in control subjects than diabetic patients - DR2: $27 \%$ vs $7 \%, p_{\mathrm{c}}<0.04$, RR 0.19, EF - 0.28; DR7: $31 \%$ vs $9 \%$, $p_{\mathrm{c}}<0.03$, RR 0.21, EF - 0.33. DR1 was less common in diabetic patients than in control subjects but this difference was not significant. None of the diabetic patients was a DR1, 4 heterozygote.

HLA-DQ $\beta$ chain gene probing using the enzyme BamH1 produced a pattern of approximately 10 distinct fragments. The patterns obtained in the Asians were similar to those obtained in white Caucasoid subjects, with no fragment unique to Asians or to white Caucasoid subjects being identified. The frequencies of $12,3.7$ and $3.0 \mathrm{~kb}$ fragments and of a $6.2 \mathrm{~kb}$ fragment (which is always associated with a $3.2 \mathrm{~kb}$ fragment) in the patient and control groups are given in Table 2.
Table 1. HLA-DR antigen frequencies in Punjabi Asians in the UK

\begin{tabular}{|c|c|c|c|c|c|c|}
\hline \multirow[t]{2}{*}{ HLA antigen } & \multicolumn{2}{|c|}{$\begin{array}{l}\text { Type } 1 \\
\text { diabetic } \\
\text { patients } \\
(n=45)\end{array}$} & $\begin{array}{l}\text { Control } \\
\text { subjects } \\
(n=96)\end{array}$ & \multirow[t]{2}{*}{$\mathrm{RR}$} & \multirow[t]{2}{*}{$\mathrm{EF}$} & \multirow[t]{2}{*}{$\mathrm{Pc}$} \\
\hline & $\overline{\text { No }}$ & $(\%)$ & $\overline{\text { No. }}(\%)$ & & & \\
\hline DR1 & 2 & (4) & $10 \quad(10)$ & 0.4 & -0.07 & NS \\
\hline DR2 & 3 & (7) & $26 \quad(27)$ & 0.19 & -0.28 & $<0.04$ \\
\hline DR3 & 37 & (82) & $36 \quad(38)$ & 7.7 & 0.72 & $<10^{-5}$ \\
\hline DR4 & 14 & (31) & (7) & 5.7 & 0.26 & $<0.003$ \\
\hline DR5 & 4 & (9) & $17 \quad(18)$ & 0.45 & -0.11 & NS \\
\hline DR7 & 4 & (9) & $30 \quad(31)$ & 0.21 & -0.33 & 0.03 \\
\hline DR3, 4 & 10 & (22) & $3 \quad(3)$ & 8.9 & 0.20 & 0.007 \\
\hline DR3 and/or 4 & 41 & (91) & $40 \quad(42)$ & 14.4 & 0.85 & $<10^{-7}$ \\
\hline
\end{tabular}

No. $(\%)=$ number (percentage) of individuals with the corresponding $\mathrm{DR}$ phenotype; $\mathrm{RR}=$ relative risk; $\mathrm{EF}=$ etiological fraction; $\mathrm{Pc}=$ significance level corrected for number of markers tested

Table 2. HLA-DQ beta chain RFLPs in Punjabi Asians in the UK

\begin{tabular}{|c|c|c|c|c|c|c|}
\hline \multirow[t]{2}{*}{$\begin{array}{l}\text { Fragment } \\
\text { (kb) }\end{array}$} & \multicolumn{2}{|c|}{$\begin{array}{l}\text { Type } 1 \\
\text { diabetic } \\
\text { patients } \\
(n=43)\end{array}$} & \multicolumn{2}{|c|}{$\begin{array}{l}\text { Control } \\
\text { subjects } \\
(n=90)\end{array}$} & \multirow[t]{2}{*}{$\mathrm{RR}$} & \multirow[t]{2}{*}{$\mathrm{Pc}$} \\
\hline & No. & $(\%)$ & No. & $(\%)$ & & \\
\hline 12 & 16 & (37) & 23 & (26) & 1.73 & NS \\
\hline $6.2+3.2$ & 5 & (12) & 32 & (36) & 0.24 & $<0.02$ \\
\hline 3.7 & 5 & (12) & 20 & (22) & 0.46 & NS \\
\hline 3.0 & 1 & (2) & 18 & (20) & 0.10 & 0.03 \\
\hline
\end{tabular}

No. $(\%)=$ number (percentage) of individuals with the fragment; $\mathrm{RR}=$ relative risk; $\mathrm{Pc}=$ significance level corrected for number of fragments tested

Associations were noted between restriction fragments and certain DR specificities in the control subjects: $12 \mathrm{~kb}$ fragment and DR4 $\left(p<10^{-3}\right)$ (all 7 DR4 positive controls were $12 \mathrm{~kb}$ positive), $12 \mathrm{~kb}$ fragment and DR7 $\left(p<5 \times 10^{-4}\right) ; 6.2+3.2$ fragments and DR1 $(p<0.005) ; 3.7 \mathrm{~kb}$ fragment and DR5 (w11) $\left(p=10^{-6}\right)$; $7.0+4.0 \mathrm{~kb}$ fragments (not shown in Table 2) and DR3 $(p<0.0005)$. No association of the $3.0 \mathrm{~kb}$ fragment was apparent.

The $12 \mathrm{~kb}$ fragment was strongly associated with DR4 in patients - all 14 DR4 positive patients studied were $12 \mathrm{~kb}$ positive, but this was the case in only three out of 29 DR4 negative patients $\left(p<10^{-7}\right)$. None of the DR4 positive patients possessed the $3.7 \mathrm{~kb}$ fragment. All 35 DR3 positive patients studied possessed the $7.0+4.0 \mathrm{~kb}$ fragments.

The combination of 6.2 and $3.2 \mathrm{~kb}$ fragments was less common in diabetic patients than in control subjects $\left(12 \%\right.$ vs $\left.36 \%, p_{\mathrm{c}}<0.02\right)$. The $\mathrm{RR}$ for the $6.2+3.2 \mathrm{~kb}$ fragment combination was 0.24 . A $3.0 \mathrm{~kb}$ fragment was found in $20 \%$ of control subjects but in only $2 \%$ (one out of 43 ) of diabetic patients $\left(p_{\mathrm{c}}<0.03\right.$ ). 


\section{Discussion}

Asian Indians can be divided into the Dravidians, mainly living in the south, and those of Indo-Aryan stock who live in the north. The UK Asian community mainly originates from India, Pakistan, Bangladesh and Sri Lanka. Asians living in Birmingham, UK are mainly from Gujerat or the Punjab. We have restricted our study to individuals from the Punjab (an area spanning northeast Pakistan to northwest India) to minimise the influence of genetic heterogeneity.

The major component of genetic susceptibility to Type 1 diabetes is HLA-linked. In most white Caucasoid populations both HLA-DR3 and DR4 are strongly associated with Type 1 diabetes so that over $95 \%$ of diabetic patients possess either or both of these markers $[11,12]$. At least $50 \%$ of healthy white Caucasoid subjects possess either or both of these markers, however, and this has led to a search for more specific markers for susceptibility to Type 1 diabetes.

Our results indicate that DR3 has a strong positive association with Type 1 diabetes in Punjabi Asians with RR 7.7 and EF 0.72 . DR4 is also significantly associated, but with a lower RR and EF. There is a very low frequency of DR4 in the control population. DR2 and DR7 are markedly reduced in diabetic patients, suggesting that these markers are associated with a protective effect.

There are few published studies on DR antigens in Asian Indians with Type 1 diabetes. A study of Indians with Type 1 diabetes in South Africa, however, showed an associated with DR3 and DR4 in Aryans but, presumably because of the small number of patients studied, no DR association in Dravidians [13]. Bhatia et al. found a strong association with DR3 but not with DR4 in north Indian Type 1 diabetic patients [14]. The frequency of DR4 in their control population, however, was higher than that found in other studies $[15,16]$. The stronger association of DR3 than of DR4 with Type 1 diabetes in Punjabi Asians contrasts with findings in the UK white Caucasoid population where DR4 has a higher RR and EF than DR3 [12]. In both groups, however, DR2 and DR7 show a negative association. The finding of a high frequency of DR1/4 heterozygotes in white Caucasoid diabetic patients [17] suggests that DR1 haplotypes may predispose to Type 1 diabetes. DR1 was, however, reduced in frequency in our diabetic patients, but this difference was not significant.

The HLA-D region comprises three sub-loci - DP, DQ and DR. The molecules encoded in this region are thought to be important in interactions between cells of the immune system [18]. The DP and DQ subregions each contain two $\alpha$ and two $\beta$ chain genes, while the DR region has one $\alpha$ chain and, usually, three $\beta$ chain genes. Until recently cellular and serological typing were the only methods for studying HLA-D region polymorphism. The development of the technique of
Southern blot hybridization analysis and the isolation of cDNA clones for HLA-D $\alpha$ and $\beta$ chains has made it possible to study the variability of this region by restriction fragment length polymorphism (RFLP) analysis. This method has been employed in the study of Type 1 diabetes in white Caucasoid subjects with a variety of HLA-D region gene probes and restriction enzymes [19-23]. Owerbach et al. showed that a probe detecting $\mathrm{DQ} \beta$ DNA sequences could differentiate DR-matched patients and control subjects [20]. A BamHI $3.7 \mathrm{~kb}$ fragment, found in $30-40 \%$ of control subjects, was rare $(0-2 \%)$ in Type 1 diabetic patients. Subsequent family studies indicated that the $3.7 \mathrm{~kb}$ fragment is a marker for a subset of DR4 chromosomes which is reduced in diabetic patients, and that the Type 1 diabetes-predisposing subset is associated with a $12 \mathrm{~kb}$ BamHI fragment [19]. DR4 is in strong linkage disequilibrium with DQw3 in white Caucasoids, but DQw3 is also found in association with DR5 and on some haplotypes expressing DR7. DQw3 can be split serologically by reagents which define a specificity designated TA10 [24]. DR5-DQw3 haplotypes are TA10-positive, while the majority of DR4-DQw3 haplotypes are TA10-negative. Kim et al. have reported, in studies of RFLPs in homozygous typing lines, that the BamHI $12 \mathrm{~kb}$ fragment is found in DQw3, TA10-negative (DQw3.2) cells, and the $3.7 \mathrm{~kb}$ fragment in DQw3, TA10-positive (DQw3.1) cells [25]. DR4 haplotypes can thus be divided into DQw3.1 and DQw3.2 subsets. These workers have reported that it is the DQw3.2 allele which is associated with Type 1 diabetes and similar results have been obtained by others [21-23].

The DR4 haplotypes in our diabetic patients are of the DQw3.2 subset which predisposes to Type 1 diabetes in white Caucasoid subjects. The number of DR4-positive control subjects in our study is too small to determine accurately what proportion of DR4 haplotypes in the general population is of this type. The BamHI $12 \mathrm{~kb}$ fragment was also associated with DR7 in the control subjects, but there was only one DR7/12 kb-positive individual amongst the Type 1 diabetic patients. This suggests that some component other than the $\mathrm{DQ} \beta$ chain, present on DR4 haplotypes, but not on DR7 haplotypes, is influencing susceptibility. In this study, DR3, both in diabetic patients and control subjects, was associated with one fragment pattern $(7.0+4.0 \mathrm{~kb}$ fragments) and, therefore, $\mathrm{DQ} \beta$ chain gene probing could not specify any DR3 subset predisposing to Type 1 diabetes. A $6.2+3.2 \mathrm{~kb}$ fragment combination was significantly less common in diabetic patients than in control subjects. This fragment pair is associated with DR1 both in our study and in white Caucasoid subjects [23]. Although DR1 haplotypes may predispose to Type 1 diabetes in white Caucasoid subjects [17], in our study this pattern is associated with a protective effect. The $3.0 \mathrm{~kb}$ fragment, which was not found in any of the patients, did not show any DR as- 
sociations in our study, but it may be associated with DRw6 [23] which was not tested for in this study.

We conclude that the major susceptibility factor so far defined for Type 1 diabetes in Punjabi Asians is HLA-DR3 with DR4 being a second predisposing factor and DR2 and DR7 protective. Gene probing indicates that the same subset of DR4 haplotypes, defined by $\mathrm{DQ} \beta$ restriction fragments, is associated with Type 1 diabetes in this racial group as in white Caucasoid subjects. DR1 and its associated $\mathrm{DQ} \beta$ restriction fragments were reduced in frequency in this group in contrast with the findings in white Caucasoid subjects. The low prevalence of Type 1 diabetes in Asian Indians remains unexplained, although the low frequency of DR4 may be partially responsible. It is likely, however, that environmental factors are also involved.

Acknowledgments. The authors are grateful to J.Anderson and S. Walford (Wolverhampton), T.C. Harvey (Walsall), P. Rayner and M. Honeyman (Birmingham Children's Hospital), B.Smith (Sandwell), A. Reynolds and K. Taylor (Dudley Road Hospital), J. Allgrove (East Birmingham paediatric diabetic clinic) for allowing us to approach their patients, C. Good and P. Mackintosh (West Midlands Blood Transfusion Centre) for advice on HLA-DR typing. The HLA-DQ $\beta$ chain probe was kindly provided by P.A. Peterson, University of Uppsala, Sweden. O.O. is a Novo research fellow, J.F. is a Medical Research Council training fellow and C.M. was supported by the British Diabetic Association.

\section{References}

1. Verma NPS, Mehra SP, Madhu S, Mather HM, Keen H (1986) Prevalence of known diabetes in an urban Indian environment: the Darya Ganj diabetes survey. Br Med J 293: 423-424

2. Sathe RV (1973) The problem of diabetes mellitus in India. J Indian Med Assoc 61: 12-16

3. Patel JC, Dhirawani MK, Kadekar SG (1966) Analysis of 5481 subjects of diabetes mellitus. In: Patel JC, Talwalker NG (eds) Diabetes in the Tropics. Diabetic Association of India, Bombay, pp 94-100

4. Vaishnava H, Bashin RC, Galati PD (1974) Diabetes mellitus with onset under 40 years in North India. J Assoc Physicians India 22: $879-888$

5. Odugbesan O, Barnett AH (1985) Asian patients attending a diabetic clinic. Br Med J 290: 1051-1052

6. Mather HM, Keen H (1985) The Southall Diabetes Survey: prevalence of known diabetes in Asian and Europeans. Br Med J 291: 1081-1084

7. Tait BD, Simons MJ (1984) Serological detection of HLA-D locus related (DR) gene products. In: Simons MJ, Tait BD (eds) Detection of immune-associated genetic markers of human disease. Churchill Livingstone, London, pp 37-45

8. Southern EM (1975) Detection of specific sequences among DNA fragments separated by gel electrophoresis. J Mol Biol 98: 503-517

9. Feinberg AP, Vogelstein B (1983) A technique for radiolabelling DNA restriction endonuclease fragments to high specific activity. Anal Biochem 132: 6-11

10. Mathews JD (1984) Statistical aspects of immunogenetic associations with disease. In: Simons MJ, Tait BD (eds) Detection of immune-associated genetic markers of human disease. Churchill Livingstone, London, pp 106-136
11. Platz $P$, Jakobsen BK, Morling $N$ et al (1981) HLA-D and -DR antigens in genetic analysis of insulin-dependent diabetes mellitus. Diabetologia 21: 108 -115

12. Wolf E, Spencer KM, Cudworth AG (1983) The genetic susceptibility to Type 1 (insulin-dependent) diabetes: Analysis of the HLA-DR association. Diabetologia 24: 224-230

13. Omar DAK, Hammond MG, Rajput MC, Asmal AC (1984) HLA A, B, C and DR antigens in young South African Indians with insulin-dependent diabetes mellitus. S Afr Med J 66: 765-767

14. Bhatia E, Mehra NK, Taneja V, Vaidya MC, Ahuja MMS (1985) HLA-DR antigen frequencies in a north Indian type 1 diabetic population. Diabetes 34: 565-567

15. Mittal KK, Naik S, Sansonetti N, Cowherd R, Kumar R, Wong DM (1982) The HLA antigens in Indian Hindus. Tissue Antigens 20:223-226

16. Baur MP, Neugebauer M, Deppe H, Sigmund M, Luton T, Maayr WR, Albert ED (1984) Population analysis on the basis of deduced haplotypes from random families. In: Albert ED, Baur MP, Mayr WR (eds) Histocompatibility Testing 1984. Springer, Berlin Heidelberg New York Tokyo, pp 333-341

17. Winearls BC, Bodmer JG, Bodmer WF, Bottazzo GF, McNally J, Mann JI, Thorogood M, Smith MA, Baum JD (1984) A family study of the association between insulin dependent diabetes mellitus, autoantibodies and the HLA system. Tissue Antigens 24: 234-246

18. Giles RC, Capra JD (1985) Structure, function and genetics of human class II molecules. Adv Immunol 37: 1-71

19. Owerbach D, Hagglof B, Lernmark A, Holmgren G (1984) Susceptibility to insulin-dependent diabetes defined by restriction enzyme polymorphism of HLA-D region genomic DNA. Diabetes 33: 958-965

20. Owerbach D, Lernmark A, Platz P, Ryder LP, Rask L, Peterson PA, Ludvigsson J (1983) HLA-D region $\beta$-chain DNA endonuclease fragments differ between HLA-DR identical healthy and insulin-dependent diabetic individuals. Nature 303: 815-817

21. Cohen-Haguenauer O, Robbins E, Massart C, Busson M, Deschamps, Hors J, Lalouel J-M, Dausset J, Cohen D (1985) A systematic study of HLA class II- $\beta$ DNA restriction fragments in insulin-dependent diabetes mellitus. Proc Natl Acad Sci USA 82: 3335-3339

22. Nepom BS, Palmer J, Kim SJ, Hansen JA, Holbeck SL, Nepom GT (1986) Specific genomic markers for the HLA-DQ subregion discriminate between DR4 ${ }^{+}$insulin-dependent diabetes mellitus and DR4 ${ }^{+}$seropositive juvenile rheumatoid arthritis. J Exp Med 164: $345-350$

23. Bohme J, Carlsson B, Wallin J, Moller E, Persson B, Peterson PA, Rask L (1986) Only one DQ- $\beta$ restriction fragment pattern of each DR specificity is associated with insulin-dependent diabetes. J Immunol 137: 941-947

24. Bodmer JG, Kennedy LJ, Aizawa M, Dawkins RL, Lepage V, Mazzilli MC, Richiardi P (1984) HLA-D region monoclonal antibodies. In: Albert ED, Baur MP, Mayr WR (eds) Histocompatibility Testing 1984. Springer, Berlin Heidelberg New York Tokyo, pp 217-236

25. Kim SJ, Holbeck SL, Nisperos B, Hansen JA, Maeda H, Nepom GT (1985) Identification of a polymorphic variant associated with HLA-DQw3 and characterised by specific restriction sites within the DQ $\beta$-chain gene. Proc Natl Acad Sci USA 82: $8139-8143$

Received: 30 December 1986

and in revised form: 1 June 1987

Dr. A. Barnett

Department of Medicine

East Birmingham Hospital

Birmingham B9 5ST

UK 